\title{
Black Carrot (Daucus carota ssp. sativus var. Atrorubens Alef.) Extract Protects against Ethanol-induced Liver Injury via the Suppression of Phosphodiesterase $4 \mathrm{mRNA}$ Expression
}

\author{
Kitano A ${ }^{1}$, Norikura $\mathbf{T}^{2}$, Matsui-Yuasa $\mathbf{I}^{1}$, \\ Shimakawa $H^{3}$, Kamezawa $M^{3}$ and Kojima-Yuasa \\ $\mathbf{A}^{1 *}$ \\ ${ }^{1}$ Department of Food and Human Health Sciences, \\ Graduate School of Human Life Science, Osaka City \\ University, Japan \\ ${ }^{2}$ Department of Nutrition, Aomori University of Health \\ and Welfare, J apan \\ ${ }^{3}$ Konan Chemical Industry, Co., Ltd., J apan \\ *Corresponding author: Akiko Kojima-Yuasa, \\ Department of Food and Human Health Sciences, \\ Graduate School of Human Life Science, Osaka City \\ University, 3-3-138 Sugimoto, Sumiyoshi-ku, Osaka, 558- \\ 8585, J apan
}

Received: May 21, 2021; Accepted: J une 29, 2021; Published: July 06, 2021

\begin{abstract}
We examined the protective effects of Black Carrot Extract (BCE) on Alcoholic Liver Disease (ALD) using in vivo and in vitro models. In an in vivo ethanol-Carbon Tetrachloride $\left(\mathrm{CCl}_{4}\right)$-treated rat model, BCE treatment suppressed serum alanine aminotransferase and aspartate aminotransferase activity. $\mathrm{BCE}$ also suppressed ethanol- and $\mathrm{CCl}_{4}$-induced alcoholic liver disease. Furthermore, we observed that the BCE or butanol-extracted fraction of BCE (BCE-BuOH) recovered the cell viability of in vitro ethanol-treated hepatocytes. $\mathrm{BCE}-\mathrm{BuOH}$ also suppressed the production of reactive oxygen species induced by ethanol to the control level. Moreover, $\mathrm{BCE}-\mathrm{BuOH}$ regulated the activities of three alcoholic metabolism-related enzymes: cytochrome P450 2E1 activity was suppressed at the posttranslational level, alcohol dehydrogenase activity was increased at the posttranslational level, and aldehyde dehydrogenase 2 activity was increased at the transcriptional level. Novel findings in this study include an increase in intracellular Cyclic Adenosine 3',5'-Monophosphate (cAMP) levels in hepatocytes with the simultaneous addition of ethanol and BCE-BUOH and the suppression of changes in the activities of three enzymes upon treatment with an inhibitor of CAMP-dependent protein kinase. Our study also found that BCE-BuOH suppressed the expression of phosphodiesterase $4 \mathrm{~b}$ mRNA, which increased intracellular cAMP levels. These results suggest that BCE is useful for the treatment of ALD.
\end{abstract}

Keywords: Alcoholic liver disease; Hepatocytes; Phosphodiesterase 4; Black carrot extract; cAMP; Cytochrome P450 2E1

\section{Abbreviations}

BCE: Black Carrot Extract; ALD: Alcoholic Liver Disease; $\mathrm{CCl}_{4}$ : Carbon Tetrachloride; BCE-BuOH: Butanol-Extracted Fraction of BCE; cAMP: Cyclic Adenosine 3',5'-Monophosphate; ADH: Alcohol Dehydrogenase; CYP2E1: Cytochrome P450 2E1; ROS: Reactive Oxygen Species; PDE4: Phosphodiesterase 4; BCE-water: Water Soluble Fraction of BCE; $\mathrm{BCE}-\mathrm{CHCl}_{3}$ : Chloroform-Extracted Fraction of BCE; BCE-AcOEt : Ethyl Acetate-Extracted Fraction of BCE; DMSO: Dimethyl Sulfoxide; AST: Aspartate Aminotransferase; ALT: Alanine Aminotransferase; H-E: Hematoxylin \& Eosin; EVG: Wigert's Elastic Van Gieson; DCFH-DA: 2',7'-Dichlorodihydrofluorescein Diacetate; ALDH: acetaldehyde dehydrogenase; PKA: Protein Kinase A; C-3-G: Cyanidine-3-Glucoside

\section{Introduction}

Excessive drinking affects various organs, including the liver, which metabolizes alcohol. Among these effects, the most serious is Alcoholic Liver Disease (ALD), which is particularly frequently observed in Western European countries [1]. ALD presents as an initial symptom of a fatty liver in which fat deposition is seen in hepatocytes. At this stage, fat deposition ceases when the patient stops drinking.
However, if the consumption of alcohol continues, the condition will progress to alcoholic hepatitis, liver fibrosis and cirrhosis. Therefore, it is extremely important to prevent disease progression at a relatively early stage. Absorbed alcohol is typically metabolized mainly in hepatocytes, but excessive alcohol consumption causes hepatocyte damage and inflammation in the liver [2-5].

Oxidation of ethanol to acetaldehyde in hepatocytes is performed by Alcohol Dehydrogenase (ADH) present in the cytoplasm, Cytochrome P450 2E1 (CYP2E1) present in microsomes, and catalase present in peroxisomes [6,7]. Normally, ethanol is mainly metabolized by $\mathrm{ADH}$, but heavy and chronic drinking induces CYP2E1 mRNA, increases its enzyme activity, and subsequently enhances the metabolism of alcohol in the microsomal oxidation system [8-10].

CYP2E1 has a higher Km value (Michaelis-Menten) constant for ethanol than $\mathrm{ADH}$. The role of CYP2E1 in alcohol metabolism is lower at lower blood alcohol levels, but its activity increases with increasing blood alcohol levels. Under conditions of chronic consumption of alcohol, CYP2E1 accounts for half of alcohol metabolism [11]. CYP2E1 plays an important role in alcohol metabolism; however, it produces reactive oxygen species (ROS). Overproduction of ROS 
induces inactivation of enzymes, DNA damage, and lipid peroxidation $[12,13]$. In recent years, there has been increasing interest in the involvement of ROS generated in the metabolism of alcohol as the pathogenesis of alcoholic liver disease. In the metabolism of alcohol, the production of ROS, the peroxidation of lipids, and the depletion of hepatic antioxidant enzymes result in an imbalance in the ROS production system and elimination system, resulting in excessive oxidative stress $[14,15]$. Oxidative stress is involved in the onset and progression of various diseases, including alcoholic liver disease. Therefore, it is important to suppress ROS production or to scavenge ROS to prevent hepatocellular injury [16,17]. We have shown that Ecklonia cava polyphenol treatment with ethanol inhibited CYP2E1 expression and ROS production. Furthermore, the changes in CYP2E1 activity were suppressed by treatment with H-89, an inhibitor of Cyclic Adenosine 3',5'-Monophosphate (cAMP)dependent protein kinase. Other researchers have also reported that cAMP is involved in the regulation of alcoholic metabolism-related enzyme activities [18-20].

Black carrot (Daucus carota ssp. sativus var. Atrorubens Alef.) originated from countries in Central Asia such as Turkey, Afghanistan, Egypt, India and Pakistan. Recently, it is found that Black carrots contain bioactive compounds which have antioxidant activity, anti-inflammatory ability and anti-proliferative ability and people have begun to be interested in its usefulness in human health. Therefore, the consumption of black carrots is increasing especially in Western Europa [21,22]. The main bioactive compounds in black carrots are anthocyanins, water-soluble pigments. It is reported that major anthocyanins consist of two nonacylated cyanidin derivatives such as cyanidin-3-xylosylgalactoside and cyanidine 3-xylosylglucosylgalactoside and three acylated cyanidine derivatives such as sinapic acid derivative of xylosylglucosylgalactoside, ferulic acid derivative of cyanidine xylosylglucosylgalactoside and p-coumaric acid derivative of cyanidine xylosylglucosylgalactoside $[23,24]$. Furthermore, it is also reported that black carrots contain significant amounts of phenolic acids such as chlorogenic acid, caffeic acid, caffeoylquinic acid, sinapic acid, ferulic acid and cumaric acid besides anthocyanins [25]. Black Carrot Extract (BCE) reported to prevent a myriad of degenerative diseases and a variety of cancer [22].

In this study, we investigated the preventive effect of BCE on alcohol-induced liver injury using in vivo and in vitro models. In particular, we focused on the effect of BCE on the metabolism of cAMP and found that black carrot extract prevented the expression of Phosphodiesterase 4 (PDE4) and then increased the intracellular cAMP levels in alcohol-treated hepatocytes.

\section{Materials and Methods}

\section{Preparation of BCE}

The black carrot was crushed and extracted with 50\% ethanol at room temperature. The extract was evaporated and then freeze-dried overnight to completely remove the solvent. Furthermore, BCE was diluted 20-fold with water and fractionated with chloroform, ethyl acetate and butanol. $\mathrm{BCE}-\mathrm{BuOH}$ and water soluble fraction of $\mathrm{BCE}$ (BCE-water) were dissolved in water and filter sterilized immediately before addition to the culture medium. On the other hand, Chloroform-Extracted Fraction of $\mathrm{BCE}\left(\mathrm{BCE}-\mathrm{CHCl}_{3}\right)$ and Ethyl Acetate-Extracted Fraction of BCE (BCE-AcOEt) were dissolved in

\section{Dimethyl Sulfoxide (DMSO).}

\section{Animals and experimental protocol}

The animal experiment complied with the regulations of the Osaka City University Laboratory Animal Committee (Permission number: S0056) and was conducted in accordance with the Guidelines for Proper Conduct of Animal Experiments of Science Council of Japan. Male Wister rats (8 weeks old) were purchased from Japan SLC, Inc. (Shizuoka, Japan). The rats were housed in cages one by one in a temperature-controlled room $\left(25 \pm 1^{\circ} \mathrm{C}\right)$ with a $12: 12 \mathrm{~h}$ light/ dark cycle (lights were turned on at 8:00 a.m.) and fed standard chow and tap water for 7 days (an adaptation period). Then, rats were randomly divided into four groups $(n=5)$. The control group (C) was fed a control diet and tap water. The ethanol+carbon tetrachloride $\left(\mathrm{CCl}_{4}\right)$ group (ET) was fed a control diet, $5 \%$ ethanol and $\mathrm{CCl}_{4}(0.1$ $\mathrm{ml} / \mathrm{kg}$ of body weight), and the $\mathrm{CCl}_{4}$ group (T) was fed a control diet, tap water and $\mathrm{CCl}_{4}(0.1 \mathrm{ml} / \mathrm{kg}$ of body weight). The BCE group (B) was fed a $0.48 \%$ BCE diet, $5 \%$ ethanol and $\mathrm{CCl}_{4}(0.1 \mathrm{ml} / \mathrm{kg}$ of body weight). The diet composition is shown in Table 1 . The dose of $\mathrm{CCl}_{4}$ was $0.1 \mathrm{ml} / \mathrm{kg}$ body weight mixed with olive oil at a ratio of $1: 3(\mathrm{v} / \mathrm{v})$. To create a simple and effective alcoholic liver disease animal model, rats were given $5 \%$ ethanol diluted in tap water ad libitum for 3 weeks and were simultaneously administered a low concentration of $\mathrm{CCl}_{4}$ intraperitoneally twice a week, which would not cause liver damage by single administration [26]. The histological changes of the liver in 5\% ethanol and $\mathrm{CCl}_{4}$-induced rats were similar to those found in human alcoholic cirrhosis as reported in our previous papers [27-29]. Rats were sacrificed at $48 \mathrm{~h}$ after the final $\mathrm{CCl}_{4}$ dose. After collecting blood from the inferior vena cava, each organ was removed. The organs were washed with physiological saline and weighed. A small piece of every liver was fixed with $10 \%$ neutral buffered formalin for several days and then used for histological analysis. The remaining tissues were stored frozen at $-80^{\circ} \mathrm{C}$. The collected blood was centrifuged (1500×g for $10 \mathrm{~min})$ to obtain serum.

\section{Biochemical assay of liver damage}

Serum aspartate aminotransferase (AST) and alanine aminotransferase (ALT) activities were measured by using a transaminase CII-test kit (Fujifilm Wako pure chemical Co., Osaka

Table 1: Composition of experimental diets

\begin{tabular}{|l|c|c|}
\hline \multicolumn{1}{|c|}{ Components (g) } & Control & $\mathbf{0 . 4 8 \% ~ B C E}$ \\
\hline Casein & 140 & 140 \\
\hline L-cystine & 1.8 & 1.8 \\
\hline Cornstarch & 465.692 & 460.892 \\
\hline a-cornstarch & 155 & 155 \\
\hline Sucrose & 100 & 100 \\
\hline Soybean oil & 40 & 40 \\
\hline Cellulose powder & 50 & 50 \\
\hline AIN-93M mineral mix & 35 & 35 \\
\hline AIN-93 vitamin mix & 10 & 10 \\
\hline Choline Hydrogen Tartrate & 2.5 & 2.5 \\
\hline tert-Butylhydroquinone & 0.008 & 0.008 \\
\hline BCE & 0 & 4.8 \\
\hline Total (g) & 1000 & 1000 \\
\hline
\end{tabular}


Japan).

\section{Histopathological analysis of liver}

Samples of liver tissue were fixed with $10 \%$ neutral buffered formalin for several days and then dehydrated with a graded alcohol series. After treatment with xylene, the samples were embedded in paraffin blocks and serially sectioned at $5-\mu \mathrm{m}$ thickness. Hepatocyte damage and fibrosis were assessed using Hematoxylin \& Eosin ( $\mathrm{H}-$ E) and Wigert's elastic Van Gieson (EVG) staining, respectively. The pathologist was blinded to the groups of rats.

\section{Isolation and culture of hepatocytes}

Hepatocytes were isolated by perfusion with collagenase solution from 10 12-week-old male Wistar rats under sodium pentobarbital anesthesia. Cell viability was measured using $0.4 \%$ trypan blue solution. Cells with greater than $90 \%$ viability were used in the experiment. The cells $\left(1.0 \times 10^{5} \mathrm{cells} / \mathrm{ml}\right)$ were cultured in Williams' $\mathrm{E}$ medium containing $10 \%$ fetal bovine serum. After preculture for 24 $\mathrm{h}$, cells were cultured with $100 \mathrm{mM}$ ethanol and with or without BCE.

\section{Cell viability}

Cell viability was measured by neutral red assay [30]. Neutral red solution $(0.4 \%)$ was diluted 80 times with PBS. After removing the medium, the cells were incubated with the solution for $2 \mathrm{~h}$. Then, the cells were washed with a mixture of $1 \%$ formaldehyde and $1 \%$ calcium chloride, and neutral red was extracted from the hepatocytes with a mixture of $1 \%$ acetic acid and $50 \%$ ethanol for $30 \mathrm{~min}$.

The optical density was measured with a spectrophotometer at $540 \mathrm{~nm}$. Cell viability was obtained as a percentage of the value of control cells.

\section{Intracellular ROS formation}

The measurement of intracellular ROS was examined using 2',7'-Dichlorodihydrofluorescein Diacetate (DCFH-DA) (Fujifilm Wako Pure Chemical Co., Osaka Japan), which fluoresces upon oxidation by ROS [28]. Briefly, $5 \mu$ l of $2.4 \mathrm{mM}$ DCFH-DA was added to the culture medium $30 \mathrm{~min}$ before the end of the culture. Then, the cells were washed twice with PBS and allowed to adhere to a cover glass $(24 \times 24 \mathrm{~mm})$ to the bottom of the dish. Excess water was removed, and the cells were observed under an LS101 fluorescence microscope (Olympus Corporation, Tokyo, Japan).

\section{CYP2E1 activity assay}

CYP2E1 activity was detected by the oxidation of p-nitrophenol to p-nitrocatechol. Cells were washed twice with PBS and then suspended in hypotonic buffer. The cells were disrupted both with freeze-thawing and sonication (Bioruptor UCD-250, COSMO BIO
Co., Ltd., Tokyo, Japan) and then centrifuged at $2000 \mathrm{rpm}$ using a centrifuge (MX-160 high speed refrigerated microcentrifuge, TOMY SIKO Co., Ltd., Tokyo, Japan) at $4^{\circ} \mathrm{C}$ for $20 \mathrm{~min}$. This supernatant was used for the enzyme assay. To the supernatant was added $100 \mathrm{mM}$ $\mathrm{KH}_{2} \mathrm{PO}_{4}$ with $\beta$-NADPH, and the mixture was heated in a thermostat at $37^{\circ} \mathrm{C}$ for $5 \mathrm{~min}$. Then, the $\mathrm{p}$-nitrocatechol solution (containing 0.2 $\mathrm{mM}$ p-nitrophenol and $5 \mathrm{mM} \mathrm{MgCl}, \mathrm{pH}$ 6.8) was added, and the mixture was further heated for 20 minutes. The reaction was stopped by adding $0.6 \mathrm{~N}$ perchloric acid, and the reaction mixture was mixed with $10 \mathrm{~N} \mathrm{NaOH}$. The absorbance was measured at $546 \mathrm{~nm}$ using a spectrophotometer (V-730 Bio, JASCO Corporation., Tokyo, Japan).

\section{Assay of ADH and Acetaldehyde Dehydrogenase (ALDH) activities}

Cells were washed twice with PBS and collected with cold PBS. After centrifugation, cells were suspended in buffer (50 mM HEPES, $0.25 \mathrm{M}$ sucrose, $1 \mathrm{mM}$ EDTA, $1 \mathrm{mM}$ DTT, $3 \mathrm{mM} \mathrm{MgCl}_{2}$ ), sonicated and then centrifuged at $15000 \mathrm{rpm}$ at $4^{\circ} \mathrm{C}$ for $20 \mathrm{~min}$. The supernatant was used for the enzyme assay. ADH activity was measured in 1.5 $\mathrm{ml}$ buffer solution (50 mM HEPES, $10 \mathrm{mM} \mathrm{MgCl}, 1 \mathrm{mM}$ DTT 300 $\mu \mathrm{M} \mathrm{NAD}^{+}$) plus $50 \mu \mathrm{l}$ ethanol. ALDH activity was measured in 1.5 $\mathrm{ml}$ buffer solution (50 mM HEPES, $10 \mathrm{mM} \mathrm{MgCl}, 1 \mathrm{mM}$ DTT, 300 $\mu \mathrm{M} \mathrm{NAD}{ }^{+}$) plus $50 \mu \mathrm{l}$ acetaldehyde. The supernatant and ethanol or acetaldehyde were added to the buffer solution and reacted for 3 minutes, and the increase in absorbance for 3 minutes at $340 \mathrm{~nm}$ was measured using a UV-visible spectrophotometer V-730 BIO (JASCO, Tokyo, Japan).

\section{Quantitative real time-PCR analysis}

Extraction of total RNA was performed using a High Pure RNA Isolation Kit (Roche, Basel, Switzerland), and cDNA was synthesized using a PrimerScript RT Reagent Kit (Takara Bio, Kyoto, Japan) and a thermal cycler. The quality of total RNA was assessed by an Agilent 2100 Bioanalyzer with 2100 expert software Ver 02.06 (Agilent, Tokyo, Japan). cDNA was synthesized using the iScript cDNA Synthesis Kit (Bio-Rad Lab. Inc., Tokyo, Japan) followed by qPCR using iTaq Universal SYBR Green Supermix (Bio Rad) on an ABI 7500 Fast Real-Time PCR System (Life Technologies). The sequences of the primers are described in Table 2.

The mRNA expression levels were normalized to $\beta$-actin. StepOne software v2.2.2 (Thermo Fisher Sciences) was used for the delta CT analysis.

\section{Western blot analysis}

Western blot analysis was performed according to our previous report [31]. An anti-CYP2E1 antibody (Enzo Life Sciences, Inc.,

Table 2: The sequence of the primers.

Table 2: The sequence of the primers.
\begin{tabular}{|c|c|c|}
\hline & Sense & Antisense \\
\hline Adh1 & 5'-CATTGCCGTGGACATCAACA-3' & 3'-TGGCAGCTTAACAGGGCAGA-5' \\
\hline Cyp2e1 & 5'-ATGGAAGGATGTGCGGAGGT-3' & 3'-GGCTGGCCTTTGGTCTTTTTG-5' \\
\hline Aldh2 & 5'-AACTGGAAACGTGGTGGTGA-3' & 3'-ACCAACCTCAGTGGAACCTGT-5' \\
\hline Pde4a & 5'-AGCTTGAACACCAACGTCCC-3' & 3'-CTCCAGCGTACTCCGACACA-5' \\
\hline Pde4b & 5'-ACAGGGAGACAAAGAACGGGA-3 & 3'-ACCAACCTGGGACTTTTCCAC-5' \\
\hline Pde4d & 5'-TCCGAATAGCGGAGCTGTCT-3' & 3'-TAGGCCACGTCAGCATGGTA-5' \\
\hline$b$-actin & 5'-GGAGATTACTGCCCTGGCTCCTA-3' \\
\hline
\end{tabular}


Farmingdale, NY, USA), an anti-ADH1 antibody (Cell Signaling Technology, Inc., Danvers, MA, USA) and an anti-ALDH2 antibody (Santa Cruz Biotechnology, Inc., Dallas, TX, USA) were used as primary antibodies and dissolved in Can Get Signal Immunostain Immunoreaction Enhance Solution A (TOYOBO, Osaka, Japan). Biotinylated goat anti-rabbit immunoglobulin served as a secondary antibody (DAKO, Glostrup, Denmark) and was dissolved in Can Get Signal Immunostain Immunoreaction Enhance Solution B. Then, the membrane was incubated with horseradish peroxidasecoupled streptavidin. EZ West Lumi was used for color development. Densitograph Software Library CS Analyzer ver. 3.0 (ATTO Corporation, Tokyo, Japan) was used for densitometric analysis of the protein bands.

\section{Intracellular CAMP amount}

The amount of intracellular cAMP was measured using a DetectX Direct Cyclic AMP enzyme immunoassay kit (Arbor Assays Inc. Ann Arbor, MI. USA).

\section{Statistical analysis}

Data are presented as the mean \pm SEM or mean \pm SD. Statistical analysis was performed using Statcel 3 the useful add-in forms on Excel statistical software (OMS publishing Inc., Japan). For multiple comparisons, the Tukey-Kramer method was used. The significant difference test was performed at a risk rate of $5 \%$ or $1 \%$.

\section{Results}

\section{The effects of BCE treatment on body weight and organ} weight in ethanol- and $\mathrm{CCl}_{4}$-treated rats

We examined the effect of BCE on body weight and organ weight in ethanol- and $\mathrm{CCl}_{4}$-treated rats. As shown in Figure 1, the body weights of ethanol-fed rats (group (ET) and group (B)) were significantly reduced compared with control rats. The amount of food intake in the ethanol-fed rats also decreased compared with that in the control rats (data not shown). However, no significant difference in organ weights per body weight was noted among the four groups (data not shown).

The effect of BCE treatment on serum AST and ALT activities in ethanol- and $\mathrm{CCl}_{4}$-treated rats

To determine the effect of BCE on liver injury, we measured

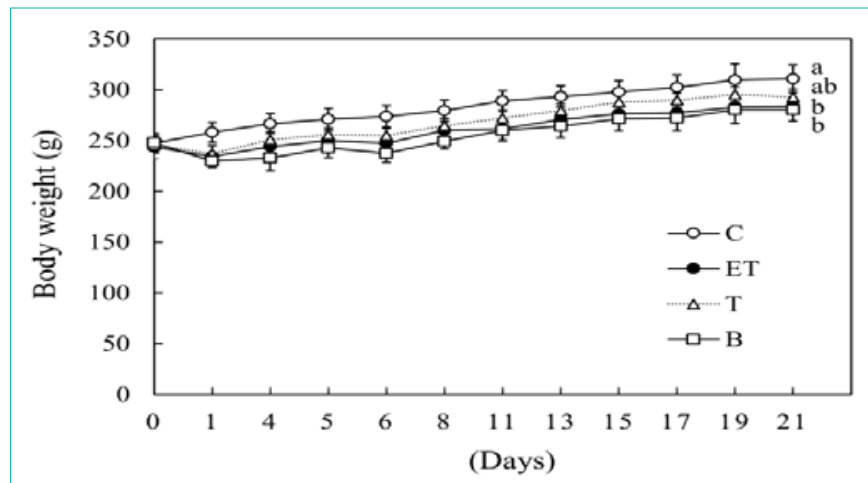

Figure 1: Effect of BCE on changes in body weight. C: control diet; ET: control diet with $5 \%$ ethanol and $\mathrm{CCl}_{4}(0.1 \mathrm{ml} / \mathrm{kg}$ of body weight $)$; T: control diet with $\mathrm{CCl}_{4} ; \mathrm{B}: 0.48 \% \mathrm{BCE}$ diet with $5 \%$ ethanol and $\mathrm{CCl}_{4}(0.1 \mathrm{ml} / \mathrm{kg}$ of body weight). Data are presented as the mean $\pm S E(n=5)$. Values without a common letter are significantly different $(p<0.05)$. serum AST and ALT activities in the rats (Figure 2). After three weeks, the serum AST and ALT activities in the ethanol- and $\mathrm{CCl}_{4}$-treated rats were enhanced by 3.3- and 8.2-fold compared with the control group, respectively. However, the serum AST and ALT activities in $\mathrm{CCl}_{4}$-treated rats (group (T)) were the same as those of control rats. Furthermore, their activities in the ethanol-, $\mathrm{CCl}_{4}$ - and 0.48\% BCEtreated rats (group (B)) were significantly reduced compared with the ethanol- and $\mathrm{CCl}_{4}$-treated group.

\section{The effect of BCE treatment on liver fibrosis and steatosis in ethanol- and $\mathrm{CCl}_{4}$-treated rats}

To assess liver steatosis, histological analysis using H-E staining was performed. In the ethanol- and $\mathrm{CCl}_{4}$-treated rats (ET group), fat accumulation in the hepatocytes was observed, but no obvious fat accumulation was observed in the $\mathrm{CCl}_{4}$-treated rats (T group). Furthermore, fat accumulation was remarkably suppressed in the BCE (B) group (Figure 3A).

The degree of liver fibrosis was evaluated by EVG staining. Histological abnormalities in livers were not observed in the control rats (group (C)) or the $\mathrm{CCl}_{4}$ alone (T) group. On the other hand, in the livers of the EtOH (ET) group, liver fibrosis was observed. However, ethanol- and $\mathrm{CCl}_{4}$-induced liver fibrosis was not observed with BCE treatment (Figure 3B).

\section{Effect of BCE on the cell viability of ethanol-treated hepatocytes}

We have already reported that treatment of hepatocytes with

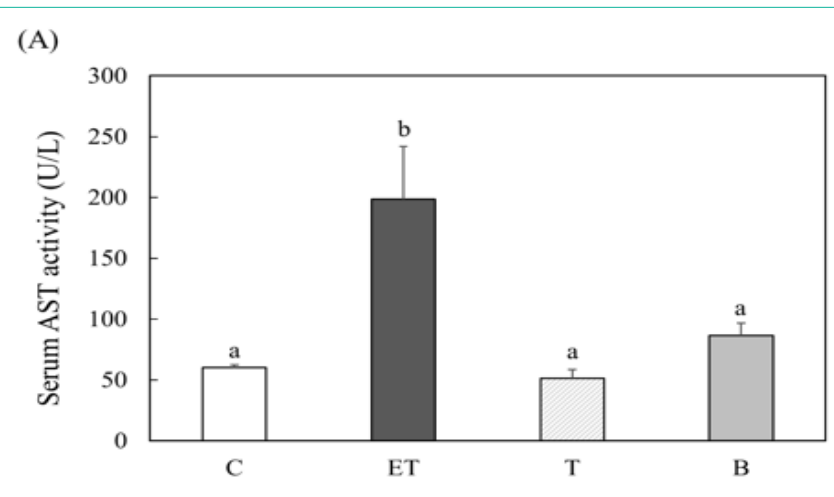

(B)

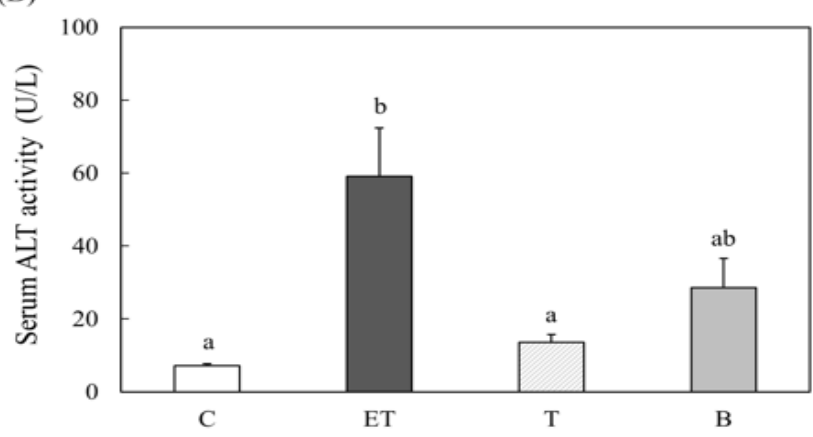

Figure 2: Effect of BCE on serum AST (A) and ALT (B) activities in ethanoland $\mathrm{CCl}_{4}$-treated rats. C: control diet; $\mathrm{ET}$ : control diet with $5 \%$ ethanol and $\mathrm{CCl}_{4}\left(0.1 \mathrm{ml} / \mathrm{kg}\right.$ of body weight); T: control diet with $\mathrm{CCl}_{4} ; \mathrm{B}: 0.48 \% \mathrm{BCE}$ diet with $5 \%$ ethanol and $\mathrm{CCl}_{4}(0.1 \mathrm{ml} / \mathrm{kg}$ of body weight). Data are presented as the mean $\pm \operatorname{SE}(n=5)$. Values without a common letter are significantly different $(p<0.05)$. 
(A)
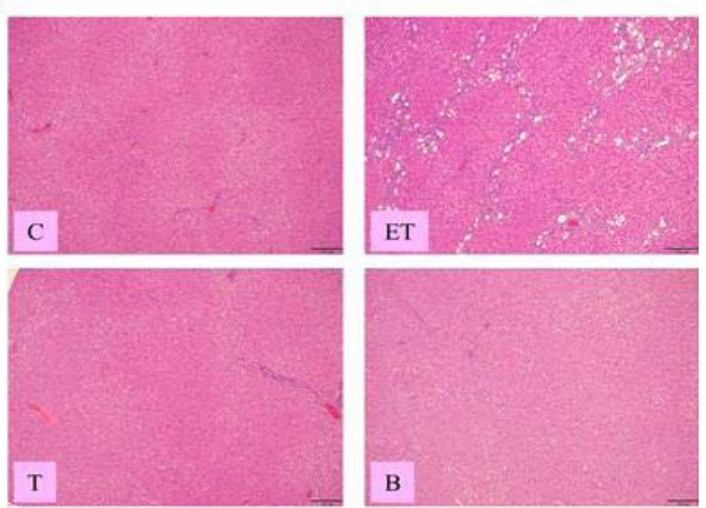

(B)
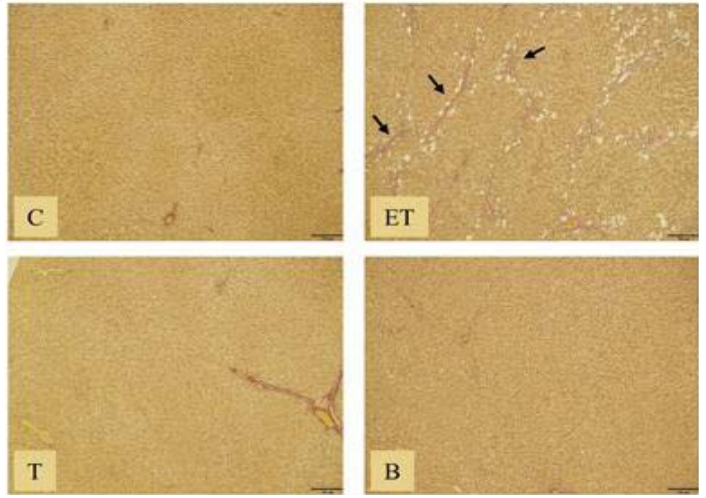

Figure 3: Effect of BCE on changes in livermorphology. Liver specimens were used for $\mathrm{H}-\mathrm{E}(\mathrm{A})$ or EVG (B) staining. C: control diet; $\mathrm{ET}$ : control diet with $5 \%$ ethanol and $\mathrm{CCl}_{4}(0.1 \mathrm{ml} / \mathrm{kg}$ of body weight); $\mathrm{T}$ : control diet with $\mathrm{CCl}$; B: $0.48 \% \mathrm{BCE}$ diet with $5 \%$ ethanol and $\mathrm{CCl}_{4}(0.1 \mathrm{ml} / \mathrm{kg}$ of body weight). Bar $=200 \mu \mathrm{m}$. Arrows indicate fibrous septa.

greater than $100 \mathrm{mM}$ ethanol causes significant cell death [27]. The blood alcohol concentration of a heavy drinker is $100 \mathrm{mM}$ to $200 \mathrm{mM}$. Therefore, we measured the cell viability of hepatocytes treated with $100 \mathrm{mM}$ ethanol and with or without BCE $(100-1000 \mu \mathrm{g} / \mathrm{ml})$ for $24 \mathrm{~h}$. The cell viability significantly decreased with the addition of ethanol. However, the cell viability was restored to the control level by the addition of $800 \mu \mathrm{g} / \mathrm{ml} \mathrm{BCE}$ (Figure 4). To examine the cytotoxicity in hepatocytes, BCE $(0-800 \mu \mathrm{g} / \mathrm{ml})$ alone was added to the hepatocytes. As a result, $\mathrm{BCE}$ did not affect cell viability at any concentration up to $800 \mu \mathrm{g} / \mathrm{ml}$ (data not shown).

\section{Effect of BCE fractions on cell viability}

We fractionated BCE with chloroform, ethyl acetate and butanol to obtain $\mathrm{BCE}-\mathrm{CHCl}_{3}, \mathrm{BCE}-\mathrm{AcOEt}, \mathrm{BCE}-\mathrm{BuOH}$ and $\mathrm{BCE}$-water, and examined the effect of these fractionFs on the cell viability of ethanol-treated hepatocytes. As shown in Figure 5, the cell viability of ethanol-treated hepatocytes was recovered in a dose-dependent manner, reaching the level of control cells by adding $400 \mu \mathrm{g} / \mathrm{ml} \mathrm{BCE-}$ $\mathrm{BuOH}$. Therefore, subsequent experiments were performed using $\mathrm{BCE}-\mathrm{BuOH}$

\section{Effect of BCE-BuOH on intracellular ROS production in ethanol-treated hepatocytes}

The ROS production in hepatocytes was examined using DCFHDA. ROS production was enhanced at $9 \mathrm{~h}$ after the addition of

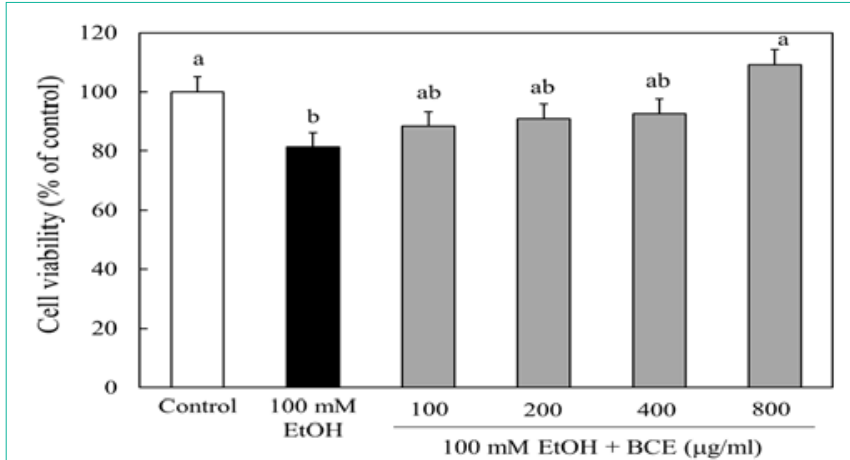

Figure 4: Effect of BCE on the cell viability of ethanol-treated hepatocytes. Hepatocytes were incubated with $100 \mathrm{mM}$ ethanol with or without various concentrations of BCE. Cell viability was measured by the Neutral Red assay as described in the Materials and Methods. Data are presented as the mean $\pm \mathrm{SD}$ of 5 experiments. Values without a common letter are significantly different $(p<0.05)$.
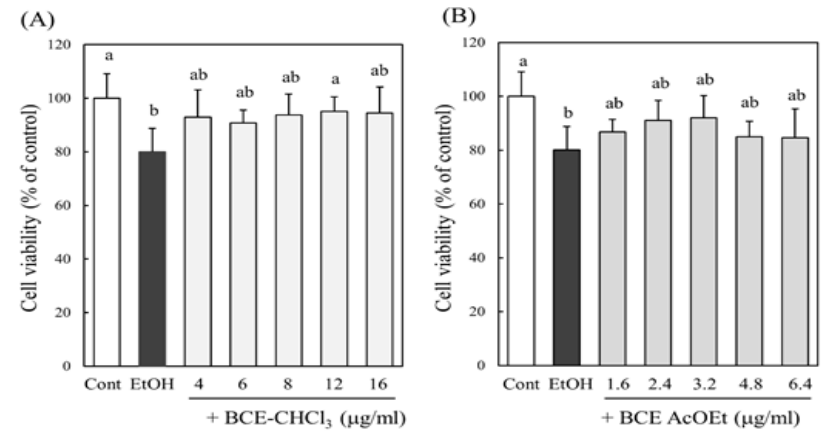

(C)
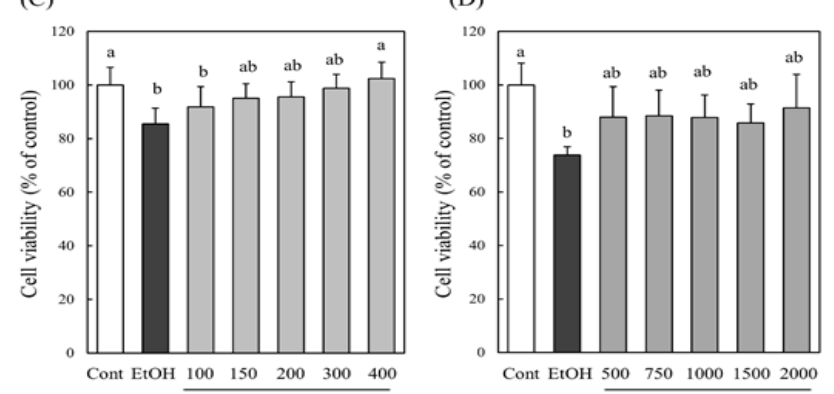

Figure 5: Effect of various fractions of BCE on the cell viability of ethanoltreated hepatocytes. Hepatocytes were incubated with $100 \mathrm{mM}$ ethanol with or without various fractions; (A) chloroform fraction $\left(\mathrm{BCE}-\mathrm{CHCl}_{3}\right),(\mathrm{B})$ ethyl acetate fraction (BCE-AcOEt), (C) butanol fraction (BCE-BuOH) and (D) water fraction (BCE-water). Cell viability was measured by the Neutral Red assay as described in the Materials and Methods. Data are presented as the mean \pm SD of 5 experiments. Values without a common letter are significantly different $(p<0.05)$.

ethanol. In contrast, when $400 \mu \mathrm{g} / \mathrm{ml} \mathrm{BCE}-\mathrm{BuOH}$ was added to the culture with ethanol, ROS production was suppressed to the control level (Figure 6).

\section{Effect of BCE-BuOH on CYP2E1 activity and its expression of $\mathrm{mRNA}$ and enzyme proteins}

We examined the effect of $\mathrm{BCE}-\mathrm{BuOH}$ on the activity and expression of CYP2E1, which is the main cause of intracellular ROS production. The addition of $100 \mathrm{mM}$ ethanol significantly increased 


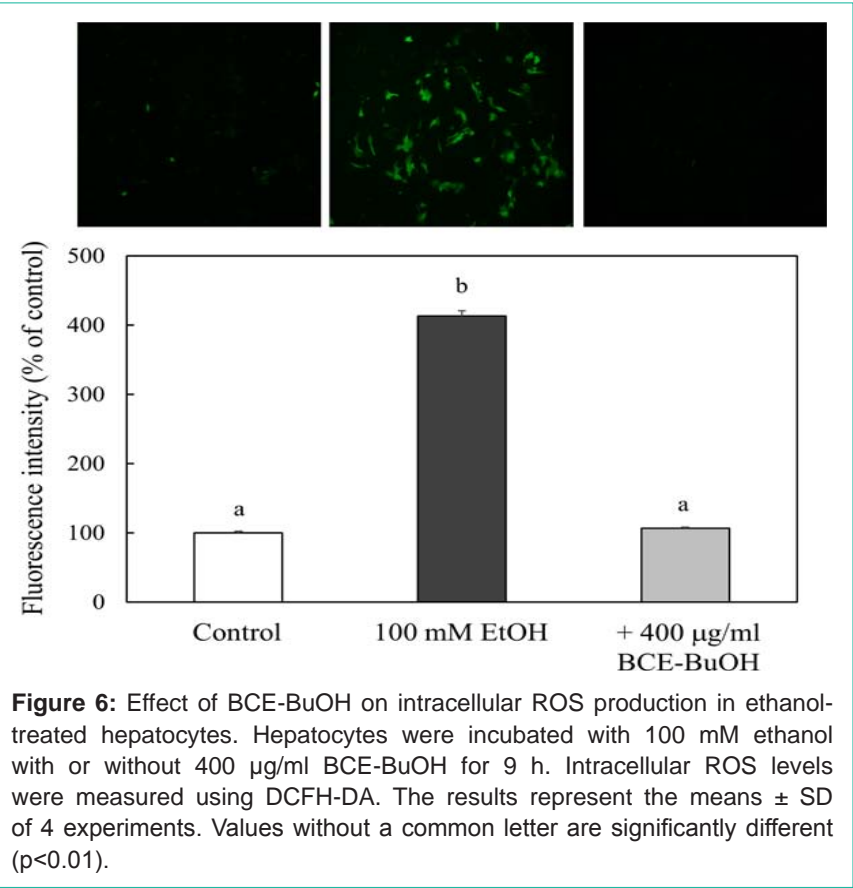

CYP2E1 activity compared to the control. On the other hand, the ethanol-induced increase in CYP2E1 activity was significantly suppressed to the control level upon the simultaneous addition of $\mathrm{BCE}-\mathrm{BuOH}$ (Figure 7A). However, CYP2E1 mRNA expression in the ethanol-treated cells was not greater that of ethanol- and BCE$\mathrm{BuOH}$-treated cells or control cells (Figure 7B). Furthermore, the expression of enzyme proteins was not different among the three groups (Figure 7C).

\section{Effect of BCE-BuOH on ADH activity and its expression of mRNA and enzyme proteins}

The addition of $100 \mathrm{mM}$ ethanol did not increase $\mathrm{ADH}$ activity or protein level at $4 \mathrm{~h}$ after the addition. On the other hand, the simultaneous addition of ethanol and $\mathrm{BCE}-\mathrm{BuOH}$ significantly increased $\mathrm{ADH}$ enzyme activity and protein level (Figure 8A, and 8C). However, Adh1 mRNA expression was not altered among the control cells, ethanol-treated cells or ethanol- and BCE-BuOHtreated cells (Figure 8B).

\section{Effect of BCE-BuOH on ALDH activity and ALDH mRNA and protein expression}

ALDH activity and ALDH2 mRNA and protein levels in cells treated with ethanol and $\mathrm{BCE}-\mathrm{BuOH}$ significantly increased compared with those in control cells or ethanol-treated cells after $4 \mathrm{~h}$ of incubation (Figure 9A-9C).

\section{Effect of BCE-BuOH on intracellular cAMP levels in ethanol-treated hepatocytes}

It has been reported that cAMP is involved in the regulation of alcoholic metabolism-related enzyme activities [18-20]. Therefore, we measured the effect of $\mathrm{BCE}-\mathrm{BuOH}$ on intracellular cAMP levels in ethanol-treated hepatocytes. As shown in Figure 10, we observed an increase in the intracellular cAMP levels in hepatocytes with the simultaneous addition of ethanol and $\mathrm{BCE}-\mathrm{BuOH}$.
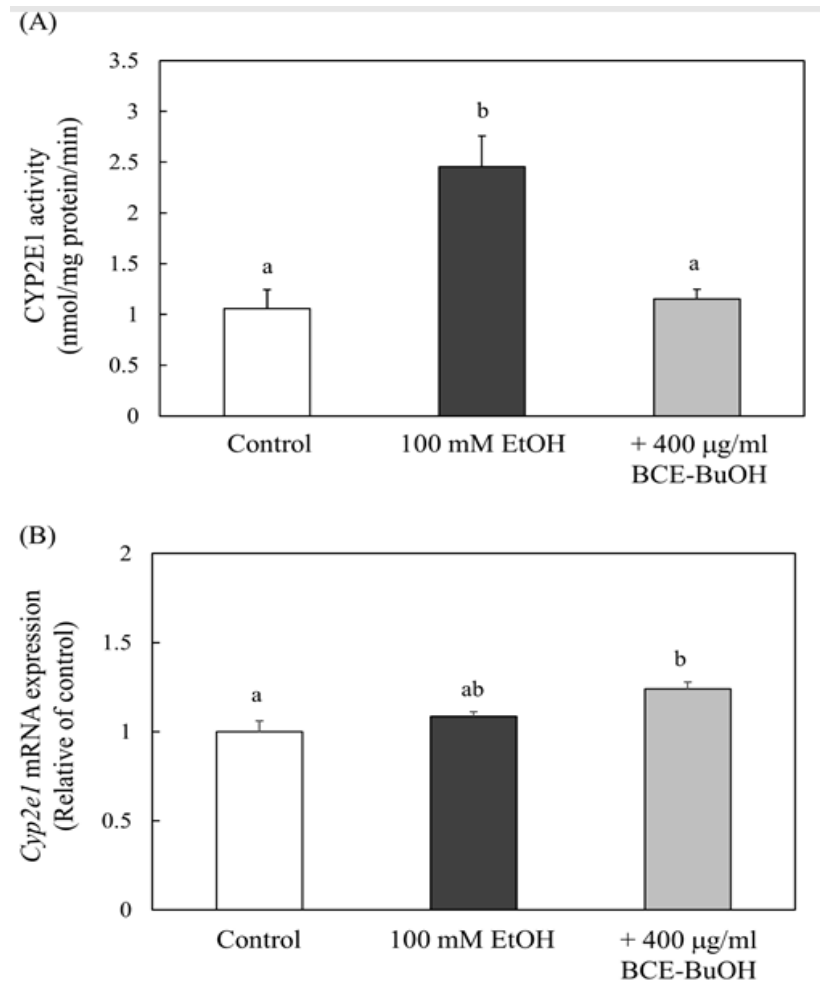

(C)

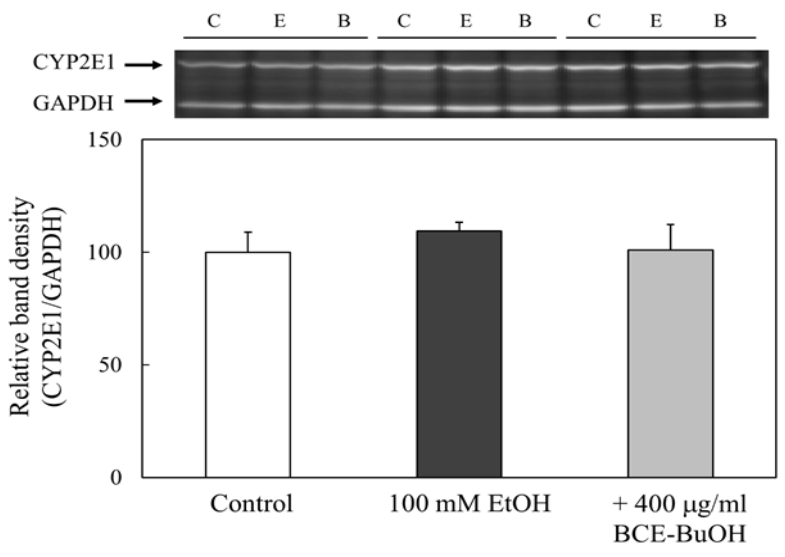

Figure 7: Effect of BCE-BuOH on CYP2E1 activity (A), mRNA expression (B) and protein levels (C) in ethanol-treated hepatocytes. (A) Hepatocytes were incubated with $100 \mathrm{mM}$ ethanol, with or without $400 \mu \mathrm{g} / \mathrm{ml} \mathrm{BCE-BuOH}$ for 9 h. CYP2E1 activity was detected by the oxidation of p-nitrophenol to p-nitrocatechol as described in the Materials and Methods. Data are presented as the mean $\pm S D(n=5)$. (B) Hepatocytes were incubated with 100 $\mathrm{mM}$ ethanol with or without $400 \mu \mathrm{g} / \mathrm{ml} \mathrm{BCE-BuOH}$ for $6 \mathrm{~h}$. CYP2E1 mRNA expression was measured using RT-PCR analysis. Data are presented as the mean $\pm S D(n=4)$. (C) Hepatocytes were incubated with $100 \mathrm{mM}$ ethanol with or without $400 \mu \mathrm{g} / \mathrm{ml}$ BCE-BuOH for $9 \mathrm{~h}$. CYP2E1 protein was measured by Western blot analysis. Data are presented as the mean $\pm \operatorname{SD}(n=3)$. Values without a common letter are significantly different $(p<0.01)$.

Effect of Protein Kinase A (PKA) inhibition on alcoholic metabolism-related enzymes in ethanol- and $\mathrm{BCE}-\mathrm{BuOH}-$ treated hepatocytes

To determine whether the cAMP/PKA signaling pathway is involved in the regulation of $\mathrm{ADH}$ and CYP2E1 activities at the posttranslational level, we used $\mathrm{H}-89$ as an inhibitor of protein kinase 


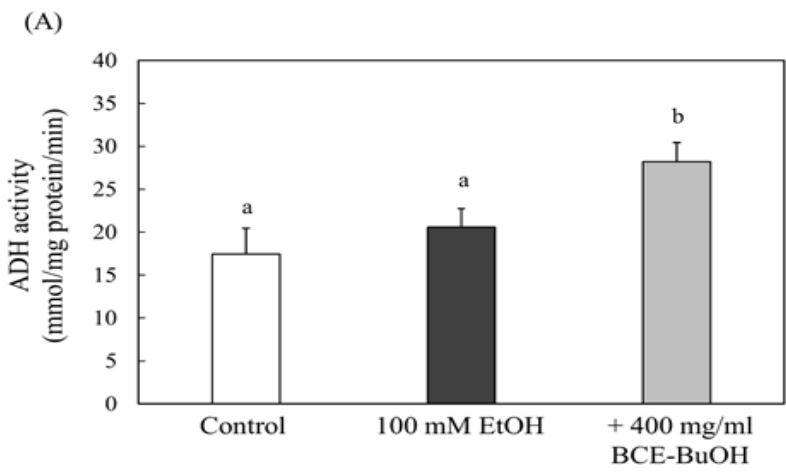

(B)

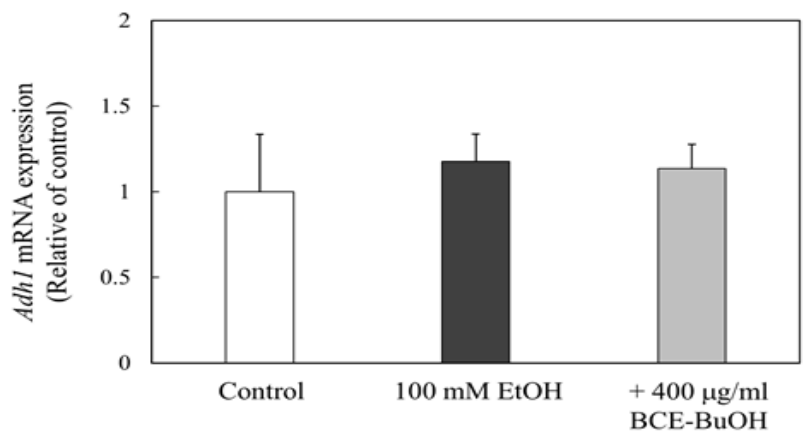

(C)

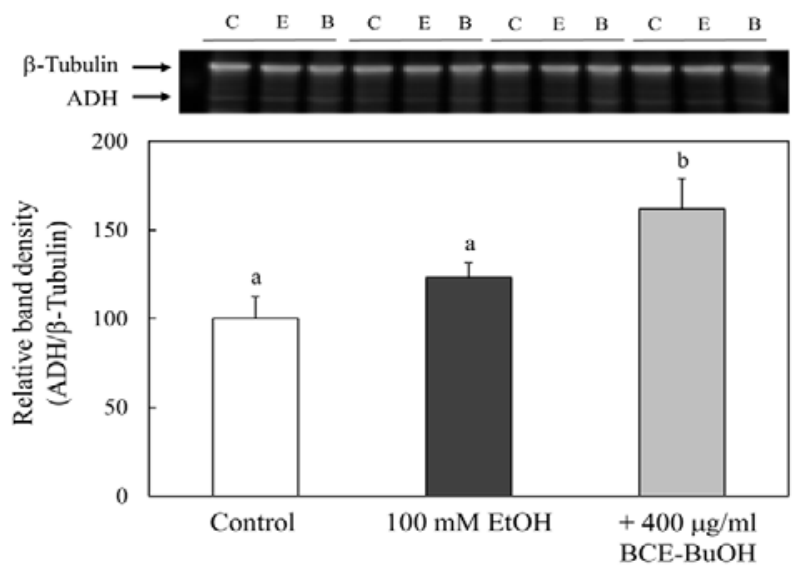

Figure 8: Effect of BCE-BuOH on ADH activity (A), mRNA expression (B) and protein levels $(C)$ in ethanol-treated hepatocytes. (A) Hepatocytes were incubated with $100 \mathrm{mM}$ ethanol with or without $400 \mu \mathrm{g} / \mathrm{ml}$ for $4 \mathrm{~h}$. ADH activity was measured as described in the Materials and Methods. Data are presented as the mean $\pm S D(n=5)$. (B) Hepatocytes were incubated with $100 \mathrm{mM}$ ethanol with or without $400 \mu \mathrm{g} / \mathrm{ml}$ for $3 \mathrm{~h}$. Adh1 mRNA expression was measured using RT-PCR analysis. Data are presented as the mean $\pm \mathrm{SD}(\mathrm{n}=4)$. (C) Hepatocytes were incubated with $100 \mathrm{mM}$ ethanol with or without $400 \mu \mathrm{g} / \mathrm{ml} \mathrm{BCE-BuOH}$ for $4 \mathrm{~h}$. ADH protein was measured by Western blot analysis. Data are presented as the mean $\pm S D(n=3)$. Values without a common letter are significantly different $(p<0.01)$.

A. The enhanced ADH activity by the treatment of ethanol and BCE$\mathrm{BuOH}$ was inhibited with the addition of $\mathrm{H}-89$ (Figure 11A). On the other hand, CYP2E1 activity suppressed by ethanol and BCE$\mathrm{BuOH}$ treatment was increased with $\mathrm{H}-89$ (Figure 11B). ALDH2 is a major enzyme involved in the metabolism of acetaldehyde in the liver. ALDH2 activity, which increased with ethanol and BCE-BuOH treatment, was inhibited by H-89 (Figure 11C).
(A)

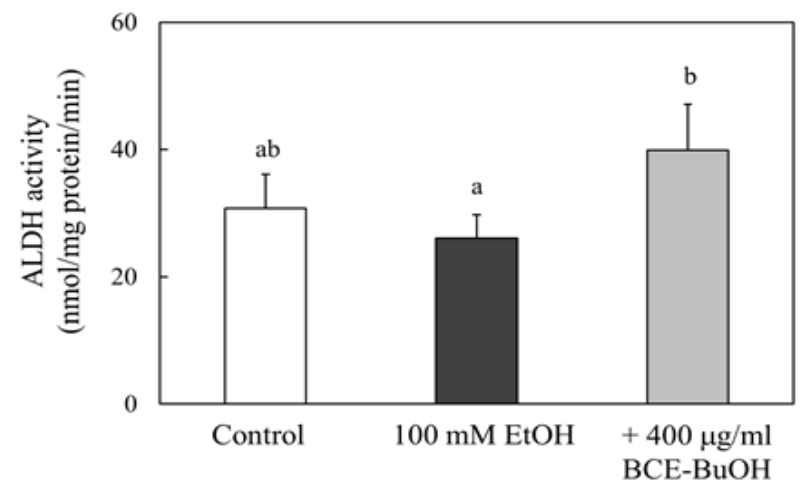

(B)

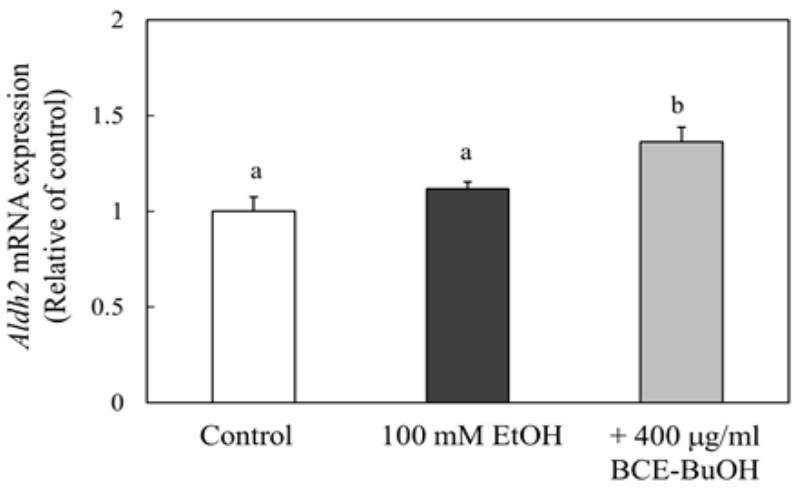

(C)

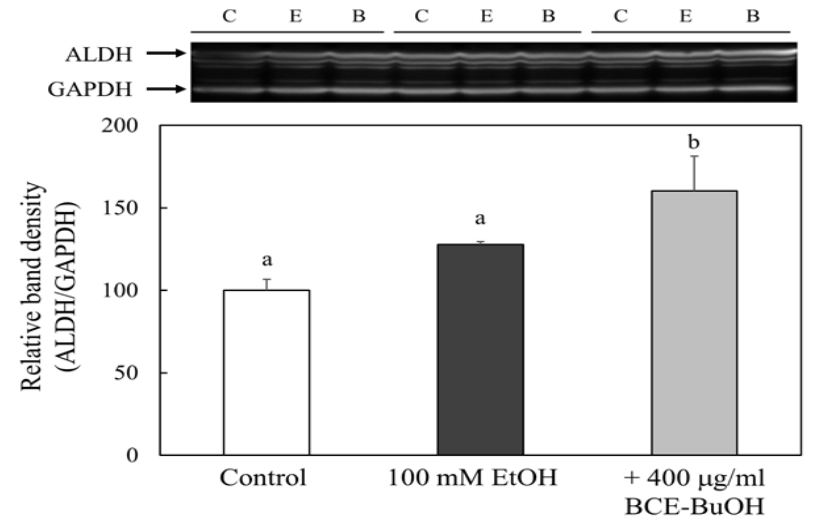

Figure 9: Effect of BCE-BuOH on ALDH activity (A), mRNA expression (B) and protein levels $(C)$ in ethanol-treated hepatocytes. (A) Hepatocytes were incubated with $100 \mathrm{mM}$ ethanol with or without $400 \mu \mathrm{g} / \mathrm{ml}$ for $4 \mathrm{~h}$. ALDH activity was measured as described in the Materials and Methods. Data are presented as the mean $\pm S D(n=5)$. (B) Hepatocytes were incubated with 100 $\mathrm{mM}$ ethanol with or without $400 \mu \mathrm{g} / \mathrm{ml}$ for $3 \mathrm{~h}$. ALDH mRNA expression was measured using RT-PCR analysis. Data are presented as the mean \pm SD $(n=4)$. (C) Hepatocytes were incubated with $100 \mathrm{mM}$ ethanol with or without $400 \mu \mathrm{g} / \mathrm{ml}$ BCE-BuOH for $4 \mathrm{~h}$. ALDH protein was measured by Western blot analysis. Data are presented as the mean $\pm S D(n=3)$. Values without a common letter are significantly different $(p<0.01)$.

\section{Effect of BCE-BuOH on PDE4 expression in ethanol- treated hepatocytes}

Avila et al. demonstrated that ethanol increased the expression of PDE4 and subsequently decreased cAMP levels and downstream 


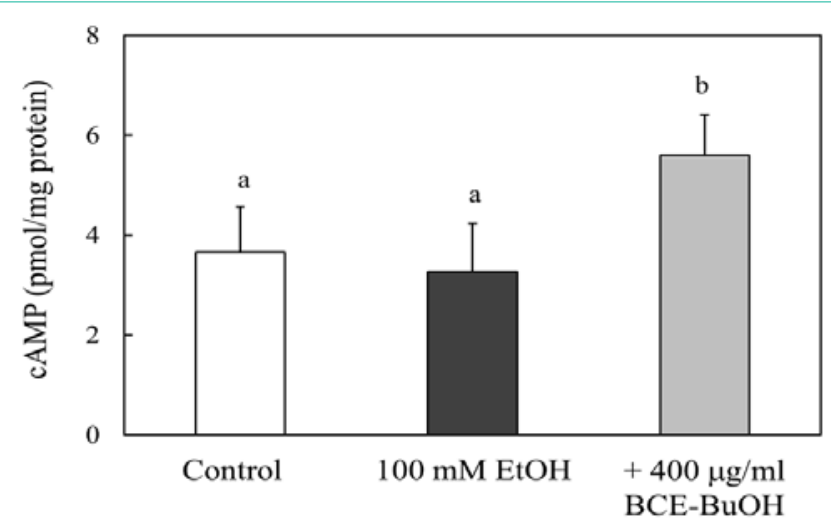

Figure 10: Effect of BCE-BuOH on intracellular cAMP levels in ethanoltreated hepatocytes. Hepatocytes were incubated with $100 \mathrm{mM}$ ethanol with or without $400 \mu \mathrm{g} / \mathrm{ml}$ for $4 \mathrm{~h}$. cAMP levels were measured as described in the Materials and Methods. The results represent the means \pm SD of 4 experiments. Values without a common letter are significantly different $(p<0.01)$.

cAMP/PKA signaling [32]. Here, we examined the effect of BCE$\mathrm{BuOH}$ on PDE4 expression and observed that ethanol and BCE$\mathrm{BuOH}$ treatment for $3 \mathrm{~h}$ significantly decreased Pde4b mRNA levels compared with ethanol-treated cells. The Pde4d mRNA level tended to decrease in cells treated with ethanol and $\mathrm{BCE}-\mathrm{BuOH}$ (Figure $12 \mathrm{~A}-12 \mathrm{C})$.

\section{Discussion}

The present study demonstrated that BCE treatment suppressed liver-to-blood leakage of AST and ALT, hepatic steatosis and liver fibrosis in ethanol- $\mathrm{CCl}_{4}$-treated rats. We also investigated the effects of BCE in an in vitro ethanol-treated hepatocyte culture system. CYP2E1 plays main roles in the production of intracellular ROS. CYP2E1 expression is regulated at both the mRNA and protein levels by various physiological conditions, such as diabetes, obesity and alcohol drinking [33,34]. Johansson et al. reported that ethanol regulated CYP2E1 posttranslationally by stabilizing the catalytically active form of the enzyme [35]. On the other hand, Wang et al. reported that CYP2E1 protein is regulated via ubiquitin-dependent proteasome degradation and that the degradation of its protein is enhanced with multisite phosphorylation by PKA and/or protein kinase C [36]. Here, we demonstrated that an increase in CYP2E1 activity due to the addition of ethanol was posttranslationally suppressed by simultaneous addition of $\mathrm{BCE}-\mathrm{BuOH}$. Furthermore, we found that its suppression was blocked by the addition of $\mathrm{H}-89$, an inhibitor of PKA (Figure 11B). These results suggest that BCE-BuOH regulates the activity of CYP2E1 posttranslationally via the cAMP/ PKA pathway.

We reported that the treatment of Ecklonia cava polyphenols increased the activities of ADH and ALDH in ethanol-treated hepatocytes in a cAMP-dependent manner [37]. Potter et al. reported that the addition of dibutyryl cAMP into hepatocytes in culture increased ADH mRNA and ADH activity at 12 and $24 \mathrm{~h}$, respectively. The effect of dibutyryl cAMP occurs at the pretranslational level given that the enhanced $\mathrm{ADH}$ activity proceeds by an increase in ADH mRNA [20]. These results suggest that cAMP has effects on $\mathrm{ADH}$ expression at different levels of regulation of $\mathrm{ADH}$ expression.
(A)

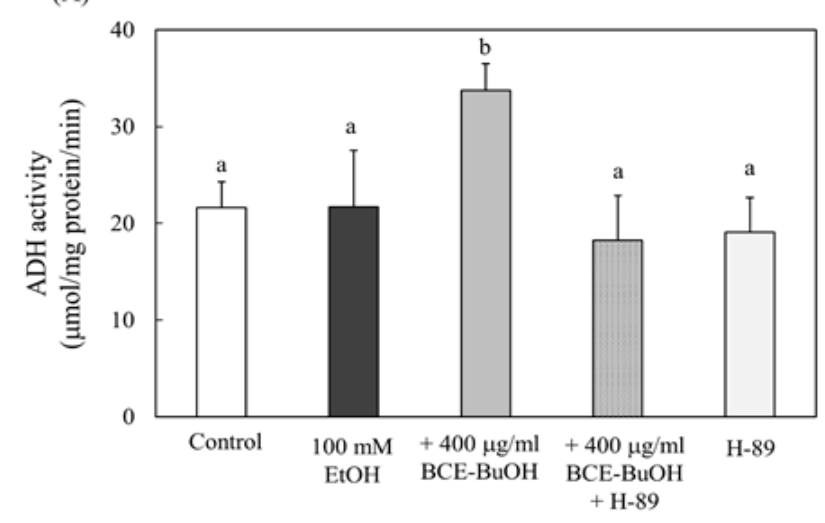

(B)

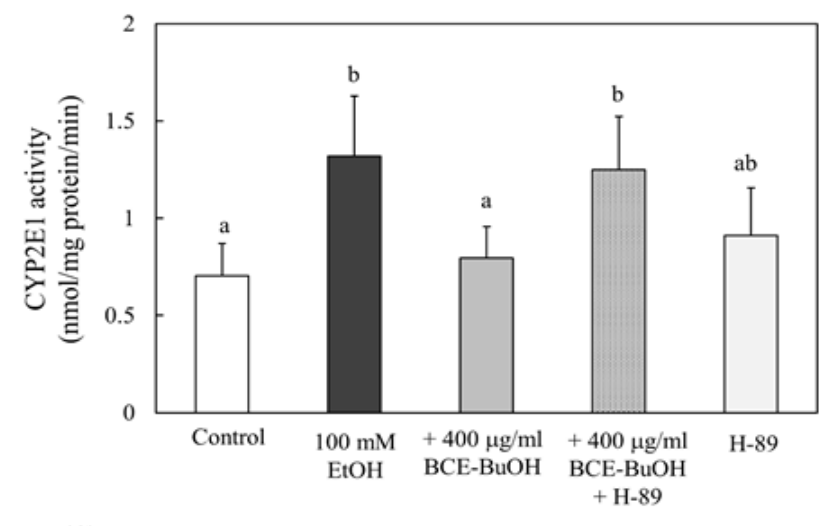

(C)

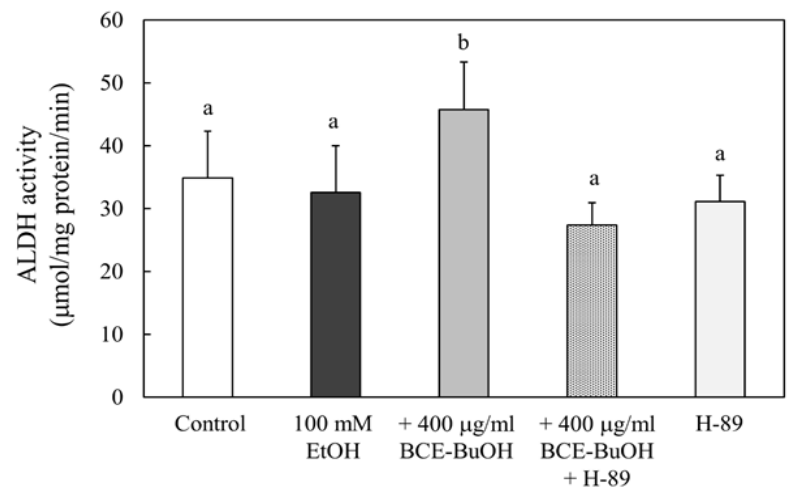

Figure 11: Effect of PKA inhibition on alcoholic metabolism-related enzymes in ethanol- and BCE-BuOH-treated hepatocytes. (A) Hepatocytes were incubated with $100 \mathrm{mM}$ ethanol with or without $400 \mu \mathrm{g} / \mathrm{ml}$ for $4 \mathrm{~h}$. (B) Hepatocytes were incubated with $100 \mathrm{mM}$ ethanol with or without $400 \mu \mathrm{g} / \mathrm{ml}$ for $9 \mathrm{~h}$. (C) Hepatocytes were incubated with $100 \mathrm{mM}$ ethanol with or without $400 \mu \mathrm{g} / \mathrm{ml}$ for $4 \mathrm{~h}$. These alcoholic metabolism-related enzyme activities were measured as described in the Materials and Methods. The results represent the means \pm SD of 4 experiments. Values without a common letter are significantly different $(p<0.01)$.

In the present study, we observed that the simultaneous treatment of ethanol and $\mathrm{BCE}-\mathrm{BuOH}$ for $4 \mathrm{~h}$ increased both $\mathrm{ADH}$ protein and $\mathrm{ADH}$ activity at the translational level. $\mathrm{ADH}$ activity was also suppressed by $\mathrm{H}-89$ treatment, suggesting that $\mathrm{ADH}$ activity was regulated translationally through the cAMP/PKA pathway.

Regarding the regulation of ALDH2 activity, we found that 


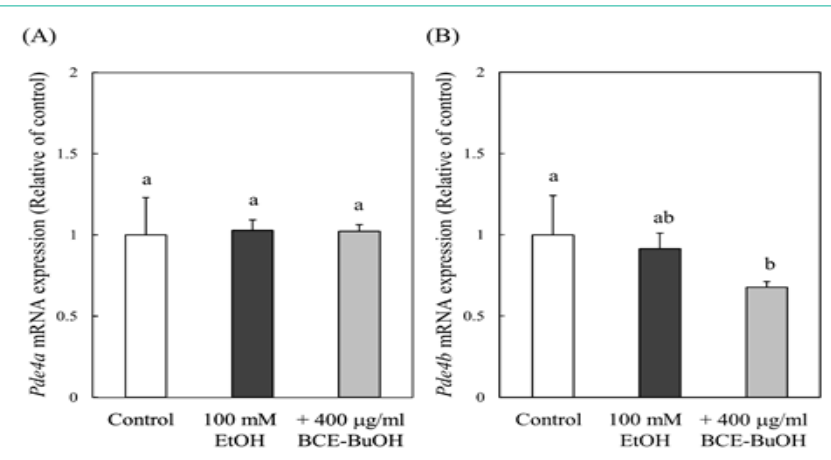

(C)

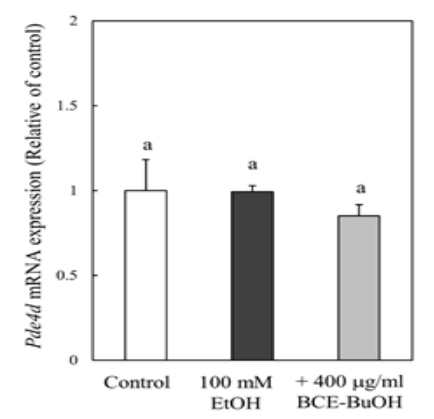

Figure 12: Effect of BCE-BuOH on the expression of PDE4 mRNA in ethanoltreated hepatocytes. Hepatocytes were incubated with $100 \mathrm{mM}$ ethanol with or without $400 \mu \mathrm{g} / \mathrm{ml}$ for $3 \mathrm{~h}$. The expression of Pde4a (A), Pde4b (B) and Pde4d (C) mRNA was measured using RT-PCR analysis. The results represent the means $\pm S D$ of 4 experiments. Values without a common letter are significantly different $(p<0.05)$.

ALDH2 mRNA and ALDH2 protein were enhanced by the treatment of ethanol and $\mathrm{BCE}-\mathrm{BuOH}$ and that the increased activity of ALDH was blocked by the addition of $\mathrm{H}-89$. Crabb et al. reported that a cAMP analog caused an increase in ALDH2 activity in rat H4IIEC3 hepatoma cells [38]. These results suggested that $\mathrm{BCE}-\mathrm{BuOH}$ regulated ALDH2 activity transcriptionally through the cAMP/PKA pathway. On the other hand, we also observed that ethanol treatment reduced ALDH2 activity slightly but not significantly. Regarding this reduction in ALDH, Agarwal et al. also reported that ethanol caused a small reduction in ALDH in the liver of alcoholics [39]. Furthermore, Crabb et al. found a similar result, in which ethanol caused a small reduction in ALDH2 activity [38].

These results indicate that the activities of ADH, ALDH and CYP2E1, which are three important enzymes involved in alcohol metabolism, are regulated by the cAMP/PKA pathway.

In our study, BCE increased intracellular cAMP levels in hepatocytes. The level of intracellular cAMP is regulated by the activities of adenylate cyclase and/or phosphodiesterase. Recently, Avila et al. reported that chronic alcoholic feeding reduced the levels of cAMP by increasing hepatic PDE4 expression [32]. Furthermore, Rodroguez et al. reported that PDE4 inhibition protected against alcohol-induced liver injury, suggesting that the inhibition of PDE4 is an effective treatment for ALD [40]. We confirmed in the present study that BCE reduced hepatic PDE4 expression.

It is very important to know what components contained in $\mathrm{BCE}$ are involved in the prevention of liver damage. Black carrots contain various kinds of polyphenols such as anthocyanins and phenolic acids. Therefore, we analyzed the polyphenol contents in the extracted fractions of BCE using the Folin-Ciocalteu method [41]. The polyphenol contents were 11.6 $\pm 0.1,46.0 \pm 1.8,11.4 \pm 1.8$ and $4.8 \pm 0.3 \%$ in $\mathrm{BCE}_{-} \mathrm{Cl}_{3}, \mathrm{BCE}-\mathrm{AcOEt}, \mathrm{BCE}-\mathrm{BuOH}$ and $\mathrm{BCE}-$ water, respectively. Polyphenols were the most abundant in BCE-AcOEt. But pigment with red and blue colors was extracted with $\mathrm{BCE}-\mathrm{BuOH}$ and BCE-water. As shown in Figure 5, the cell viability of ethanoltreated hepatocytes was recovered by adding $\mathrm{BCE}-\mathrm{BuOH}$. Therefore, we investigated the effect of Cyanidine-3-Glucoside (C-3-G), which is one of major ingredients of black carrot [22], on preventing hepatocellular injury using an in vitro alcohol-treated hepatocytes culture system. The cell viability of ethanol-treated hepatocytes was significantly recovered by adding $50 \mu \mathrm{g} / \mathrm{ml} \mathrm{C-3-G} \mathrm{(data} \mathrm{not} \mathrm{shown).}$ These results suggest that anthocyanins are effective. However, more detailed experiments are needed to clarify what kind of anthocyanin(s) is/are the active ingredient(s).

\section{Conclusions}

In conclusion, our present results indicate that BCE suppressed the release AST and ALT into the blood, hepatic steatosis and liver fibrosis in ethanol plus $\mathrm{CCl}_{4}$-treated rats. We also investigated the effects of $\mathrm{BCE}$, especially $\mathrm{BCE}-\mathrm{BuOH}$ in an in vitro ethanol-treated hepatocytes culture system, and found that the activities of three important enzymes involved in alcohol metabolism, ADH, CYP2E1 and ALDH, were up- or down-regulated via the activation of the CAMP-PKA pathway. The interesting finding is that $\mathrm{BCE}-\mathrm{BuOH}$ can increase the cAMP concentration by suppressing the expression of phosphodiesterase $4 \mathrm{~b}$ mRNA.

\section{Acknowledgment}

This work was supported by JSPS KAKENHI, Grant Number, JP15K00832. KAKENHI aims to significantly develop all "academic research" from basic to applied (research based on the free thinking of researchers).

\section{References}

1. McCullough AJ. Alcoholic liver disease. In Schiff's Diseases of the Liver, $8^{\text {th }}$ edition: Schiff, ER, Sorrell MF, Maddrly WC, Editors. Lippincott-Raven Publishers, Philadelphia, USA; 1999. pp. 941-971.

2. Nagy LE. Molecular aspects of alcohol metabolism: transcription factors involved in early ethanol-induced liver injury. Annu. Rev. Nutr. 2004; 24: 5578.

3. Bailey SM, Cunningham CC. Acute and chronic ethanol increases reactive oxygen species generation and decreases viability in fresh, isolated rat hepatocytes. Hepatology. 1998; 28: 1318-1326.

4. Lieber CS. Alcohol: its metabolism and interaction with nutrient. Annu. Rev. Nutr. 2000; 20: 395-430.

5. Yang SS, Huang CC, Chen JR, Chiu CL, Shieh MJ, Lin SJ, et al. Effects of ethanol on antioxidant capacity in isolated rat hepatocytes. World J. Gastroenterol. 2005; 11: 7272-7276

6. Comporti M, Signorini C, Leoncin S, Cordi C, Ciccoli L, Girardini A, et al. Ethanol-induced oxidative stress: basic knowledge. Genes Nutr. 2010; 5: 101-109.

7. Gao B, Bataller R. Alcoholic liver disease: pathogenesis and new therapeutic targets. Gastroentrology. 2011; 141: 1572-1585.

8. Lieber CS. Metabolism of alcohol. Clin Liver Dis. 2005; 9: 1-35.

9. Ronis MJ, Huang J, Crouch J, Mercado C, Irby D, Valentine CR, et al. 
Cytochrome P450 CYP 2E1 induction during chronic alcohol exposure occurs by a two-step mechanism associated with blood alcohol concentrations in rats. J Pharmacol Exp Ther. 1993; 264: 944-950.

10. Badger TM, Huang J, Ronis M, Lumpkin CK. Induction of cytochrome P450 2E1 during chronic ethanol exposure occurs via transcription of CYP 2E1 gene when blood alcohol concentarations are high. Biochem. Biophys. Res. Commun. 1993;190: 780-785.

11. Lieber, C.S. Ethanol methabolism, cirrhosis and alcoholism. Clin. Chim. Acta 1997, 257, 59-84.

12. Wu D, Cederbaum Al. Alcohol, oxidative stress, and free radical damage. Alcohol Res. Health. 2003; 27: 277-284.

13. Caro AA, Cederbaum Al. Oxidative stress, toxicology, and pharmacology of CYP2E1. Annu Rev pharmacol Toxicol. 2004; 44: 27-42.

14. Dey A, Cederbaum Al. Alcohol and oxidative liver injury. Hepatology. 2006 43: S63-S74.

15. Arteel GE. Oxidants and antioxidants in alcohol-induced liver disease Gastroenterology. 2003; 124: 778-790.

16. Halliwell B. Antioxidants and human disease: a general introduction. Nutr Rev. 1997; 55: S44-S49.

17. Lin Z, Ren Z, Zhang J, Chang C-C, Kandaswamy E, Zhou T, et al. Role of ROS and nutritional antioxidants in human diseases. Front. Physiol. 2018; 9: 477 .

18. Wang Y, Guan S. Ubiquitin-dependent proteasomal degradation of human liver cytochrome P4502E1: identification of sites targeted for phosphorylation and ubiquitination. J. Biochem. 2011; 286: 9443-9456.

19. Oesch-Bartlomowicz B. Differential modulation of CYP2E1 activity by cAMPdependent protein kinase upon Ser 129 replacement. Exp. Cell Res. 1998 242: 294-302.

20. Potter JJ. Regulation of the rat alcohol dehydrogenase by cAMP in primary hepatocyte culture. Arch Biochem Biophys. 1995; 321: 329-335.

21. Shebaby WN, Bodman-Smith KB, Mansour A, Mroueh M, Taleb R, El-Siba $\mathrm{M}$, et al. Daucus carota pentane-based fractions suppress proliferation and induce apoptosis in human colon adenocarcinoma HT-29 cells by inhibiting the MAPK and PI3K pathways. J Med Food. 2015; 18: 745-752.

22. Akhtar S, Rauf A, Imran M, Qamar M, Riaz M, Mubarak MS. Black carrot (Daucus carota L.), dietary and health promoting perspectives of its polyphenols: A review. Trends. Food Sci. Technol. 2017; 66: 36-47.

23. Netzel M, Netzel G, Kammerer DR, Schieber A, Carle R, Simons L, et al. Cancer cell antiproliferation activity and metabolism of black carrot anthocyanins. Innov. Food Sci Emerg Technol. 2007; 8: 365-372.

24. Kamiloglu S, Van Camp J, Capanoglu E. Black carrot polyphenols: effect of processing, storage and digestion-an overview. Phytochem Rev. 2018; 17: 379-395.

25. Gu C, Howell K, Dunshea FR, Suleria HAR. LC-ESI-QTOF/MS characterisation of phenolic acids and flavonoids in polyphenol-rich fruits and vegetables and their potential antioxidant activities. Antioxidants. 2019; 8: 405.

26. Erman F, Balkan J. Betaine or taurine administration prevents fibrosis and lipid peroxidation induced by rat liver by ethanol plus carbon tetrachloride intoxication. Amino acids. 2004; 27: 199-205

27. Takahashi M, Sakata N, Yamashita H, Tamura A, Sasaki M, Matsui-Yuasa I, et al. Ecklonia cava polyphenol protects the liver against ethanol-induced injury in rats. Biochim. Biophys. Acta. 2012; 1820: 978-988.

28. Tamura A, Sasaki M, Yamashita H, Matsui-Yuasa I, Saku T, Hikima T, et al. Yerba-mate (llex paraguararienesis) extract prevents ethanol-induced liver in rats. J Funct Foods, 2013; 5: 1714-1723.

29. Kojima-Yuasa, A.; Hirauchi, E.; Sawada, T.; Kasahara, A.; Yoshikawa, E.; Tamura, A.; Matsui-Yuasa, I. Extract of traditional pickling melon prevents ethanol-induced liver injury in rats. Int. J. Food Nutr. Sci. 2017, 6:.

30. Zhang SZ, Lipsky MM, Trump BF, Hsu IC. Nuetral Red (NR) assay for cell viability and xenobiotic-induced cytotoxicity. Cell Biol. Toxicol. 1990; 6: 219234.

31. Kato R, Matsui-Yuasa I, Azuma H, Kojima-Yuasa A. The synergistic effect of 1'-acetoxychavicol acetate and sodium butyrate on the death of human hepatocellylar carcinoma cells. Chem. Biol. Interact. 2014; 212: 1-10.

32. Avila VD, Barker FD, Zhang WJ, McClain JC, Barve S, Gobejishvili L. Dysregulation of hepatic cAMP levels via altered Pde4b expression plays a critical role in alcohol-induced steatosis. J Pathol. 2016; 240: 96-107.

33. Tanaka E, Terada M, Misawa S. Cytochrome P450 2E1: its clinical and toxicological role. Clin Pharmacol Ther. 2000; 25: 165-175.

34. Dupont I, Bodenez P, Berthou F, Simon B, Bardou IG, Lucas D. Cytochrome P4502E1 activity and oxidative stress in alcoholic patients. Alcohol Alcohol. 2000; 35: 98-103

35. Johansson I, Erasson E, Ingelman-Sundberg M. Hormone controlled phosphorylation and degradation of CYP2B1 and CYP2E1 in isolated rat hepatocytes. Biochem. Byophys Res Commun. 1991, 174, 37-42.

36. Wang YQ, Guan SH, Acharya P, Koop DR, Liu Y, Liao MX, et al. Ubiquitindependent proteasomal degradation of human liver cytochrome P450 2E1. Identification of sites targeted for phosphorylation and ubiquitination. J Biol Chem. 2011; 286: 9443-9456

37. Yamashita H, Goto M, Matsui-Yuasa I, Kojima-Yuasa A. Ecklonia cava polyphenol has a protective effect against ethanol-induced liver injury in a cyclic AMP-dependent manner. Mar Drugs. 2015; 13: 3877-3891.

38. Crabb DW, Stewart MJ, Xiao Q. Hormonal and chemical influences on the expression of class 2 aldehyde dehydrogenases in rat H4IIEC3 and human $\mathrm{HuH} 7$ hepatoma cells. Alcoholism: Clin Exp Res.1995; 19: 1414-1419.

39. Agarwal DP, Goedde HW. Biochemical aspects of alcoholism. In Alcoho metabolism, Alcohol Intolerance, and Alcoholism; Agarwal DP, Goedde HW, Editors. Springer-Verlag, Berlin. Germany. 1990: 67-95.

40. Rodriguez WE, Wahlang B, Wang Y, Zhang J, Vadhanam MV, Joshi-Barve S et al. Phosphodiesterase 4 inhibition as a therapeutic target for alcoholic liver disease: From bedside to bench. Hepatology. 2019; 70: 1958-1971.

41. Ragazzi E. Quantitative analysis of phenolic compounds after thin-layer chromatographic separation. J Chromatogr. 1973; 77: 369-375. 